\title{
Evoked Alterations In Some Biochemical Parameters And Protein Electrophoretic Pattern Of Some Tissues Of Broiler Chicken Treated With Coumarin
}

\author{
Shadia, A. Radwan \\ Department of Biology \& Geology, Faculty of Education, Ain Shams University
}

\begin{abstract}
Coumarin compounds are used as dormant substances in agriculture. Physiologically, they are highly active, for example, act as inhibitor of growth of microorganisms. Moreover, coumarin is a maturally occuring substance most frequently used as a fragrance enhancer (in cosmetics, perfumes and soap) and stabilizer. In this study, chemical analysis of chicken tissues (brain, liver and kidney) as lipid constituents, cholesterol, liver, glycogen, glutathione, lipid per oxidase and protein electrophoresis (fractions) were tested after intermuscular (i.m.) injection with doses of $100 \mathrm{mg} / \mathrm{kg}$.b.wt. and $200 \mathrm{mg} / \mathrm{kg}$.b.wt. of coumarin for 10 days (every other day). The present study revealed that coumarin at a dose of $100 \mathrm{mg} / \mathrm{kg} . \mathrm{b}$.wt. induced insignificant changes in the total lipid (T.L) of brain, liver and kidney tissues of broiler chicken. Otherwise, the high dose of coumarin ( $200 \mathrm{mg} / \mathrm{kg}$. b.wt.) caused a significant decrease in the T.L. of brain $(\mathrm{P}<0.01)$ tissues, while insignificant change of kidney T.L. was recorded at a dose of 200 $\mathrm{mg} / \mathrm{kg}$.b.wt.. of coumarin. Also, insignificant changes of triglycerides (T.G.) and cholesterol (Chol.) content of brain, liver and kidney tissues of chicken group (G2) treated with coumarin $(100 \mathrm{mg} / \mathrm{kg})$ were demonstrated. While, high dose $(200 \mathrm{mg} / \mathrm{kg}$ coumarin) resulted in a significant decrease in the T.G. and Chol. of brain ( $\mathrm{P}<0.001 \& \mathrm{P}<0.01$ respectively) and liver $(\mathrm{P}<0.001 \& \mathrm{P}<0.001)$, the same dose showed insignificant changes of kidney T.G. an Chol. contents.

Administration of coumarin $(100 \mathrm{mg} / \mathrm{kg}$. G2) showed insignificant changes in glutathione content (GSH) of liver and kidney tissues, while significant decrease $(\mathrm{P}<0.01)$ of brain GSH content was recorded compared with the control group. Besides, a dose of $100 \mathrm{mg} / \mathrm{kg}$.coumarin caused insignificant changes in lipid peroxides (TABrs) of brain and kidney tissues of chicken and significant increase $(\mathrm{P}<0.001)$ of (TABrs) content of liver tissue. High dose of coumarin (200mg./kg. G3) showed significant increase of TABrs content of brain, liver, and kidney tissues $(\mathrm{P}<0.01, \mathrm{P}<0.001$ and $\mathrm{P}<0.001$ respectively) of broiler chicken compared with the control group. Both doses of administered coumarin (G2 \& G3) caused significant decrease (P $<0.001)$ in the liver glycogen content. The present data revealed that coumarin caused qualitative and quantitative changes in tissues (brain, liver and kidney) protein fractionation pattern of chicken compared with that of controls. Sixteen bands were separated using polycrylamide gel electrophoresis (PAGE) - as protein fractions in both the control and coumarin treated groups. The changes (decrease or increase) in particular protein fractions may be related to the effect of xenobiotic (coumarin) on the specific genes encoding for these fractions. Thus, this work revealed that inspite of the benefit of coumarin substance, the xenobiotic effect and signs of intoxications were attained spacially at high doses of treatment.
\end{abstract}

Key words : Coumarin, Biochemistry, Protein electrophoretic pattern, Brain, Liver, Kidney, Broiler chicken.

\section{Introduction}

Coumarin compounds are occur naturally in the diets (Geoger and Anderson, 1991) and used as dormant substance in agriculture (inhibited seed germination) and also, inhibit the growth of microorganisms (Mohanty \& Sahoo, 1992). 
At the midical scope, coumarin drugs are used as anticoag-ulants. However, the mode of action of such usage is based on its competition with vitamin $\mathrm{K}$, preventing hepatic synthesis of various blood clotting factors. Thus, if vitamin $\mathrm{K}$ production in the intestine is inhibited (eg. by locally-acting antibacterial drugs) or its absorption is inhibited, the anticoagulant action of coumarin may increase (Rang and Dale, 1991). Moderate antitumor activity was detected after treat-ment of mice and rats (with transplanted tumor) with flavonoid compounds (coumarin containing drug) (Ryakhova-skaya et al., 1989). Carlton et al., (1996) recorded increased liver weights in male and female rats receiving 30005000 ppm of coumarin. Cholangiofibroma, cholangio-cartcinoma and parenchymal liver cell tumors were observed among male and female rats receiving 5000ppm coumarin. The authors stated that coumarin at a dose clearly exceeding the MTD (maximum tolerated dose) can, therefore induce liver tumours, in rats. In mice, at dose of 1000-2000 ppm coumarin, a decrease in body weight gain was reported - but no dose related abnormalities in clinical signs, clinical pathology, hematology or gross or microscopic pathology were noticed (Carlton et al., 1996).

Many authors concluded that the cytotoxicity of coumarin was metabolic and species dependent (Tligui and Ruth, 1994; Carlton et al. 1996; Lie-Shout et al., 1998; Lake, 1999 and Adam et al., 2005). Goeger and Anderson (1992) stated that coumarin occurs naturally in the diet - can induce and inhibit cytochrome P450 enzymes. Hepatic coumarin -7- hydroxylase activity is a major pathway for coumarin metabolism in humans but not in rats, most strains of mice, or other laboratory animals. Chick embryo liver may be a useful system for studies on the biochemical effects of coumarin and the regulation of cytochrome P450-dependent coumarin-7 hydroxylase. According to Yourick and Bronaugh (1997), coumarin absorption was significant in skin, so, systemic coumarin absorption must be expected after dermal contact with coumarin containing products. Radwan,
(2000) showed that coumarin (at doses of 100 and $200 \mathrm{mg} / \mathrm{kg}$.b.wt.) treatment caused significant decrease in serum total protein and serum globulin of mice compared the control animals. Coumarin treatment caused significant elevation in SGPT, SALP and bilirubin levels at high dose (200 $\mathrm{mg} / \mathrm{kg}$.b.wt.)only. Moreover, microscopical and ultrastructural observation of the liver and kidney of mice after coumarin treatment revealed histopathological alterations.

\section{Materials \& Methods}

Tested material and experimental design : Coumarin, [Sigma (no. C4261) crystalline benzopyrone] which is physiologically highly active, is used in this study. The structural formula of coumarin is as follows :<smiles>O=c1ccc2ccccc2o1</smiles>

For dissolving and preparing the stock solution of coumarin, $100 \mathrm{mg}$ of it was dissolved in $10 \mathrm{ml}$ of $50 \%$ ethyl alchohol, then the alchohol is evaporated in oven to reach $5 \mathrm{ml}$. Each bird received about 1.25 $\mathrm{ml}$ of this stock solution for the first dose $(100 \mathrm{mg} / \mathrm{kg}$. G2) or $2.5 \mathrm{ml}$ for second dose (200 mg/kg. G3) via intra muscular injection.

\section{Animals}

Fifteen male Balady chickens 45 day old, each about $250+50 \mathrm{~g}$ of body weight were used in this study. All experimental animals were housed in invironmentally controlled optimal conditions. Commercial food (starter) and water were provided $a d$ libitum, all birds were exposed for continuous light during the days of experimentation then, they were randomly divided into 3 groups of 5 chickens each as follows :

Group 1 (G1) : Represented the control and kept without any treatment.

Group 2 (G2) : Injected (i.m.) with coumarin at a dose of $100 \mathrm{mg} / \mathrm{kg}$ every other day for 10 days. 
Group 3 (G3) : Injected (i.m.) with 200 $\mathrm{mg} / \mathrm{kg}$. coumarin, every other day for 10 days.

After ten days of each treatment, the birds were sacrificed by decapitation, the brain, liver and kidney were quickly removed out and tissue homogenates were prepared in ice cold dist. $\mathrm{H}_{2} \mathrm{O}$. The post lysosomal supernatant of the tissue homogenate was separated and microsomal fraction was prepared by a high speed centrifugation (8000rpm) according to Dhami et al. (1979).

\section{Biochemical analysis of tissues}

Brain, liver and kidney tissue homogenates were used to determination of total lipids (T.L.) according to the method of Frings et al. (1970); triglycerides (T.G.) according to the method of Zollner and Kirsch (1982); total cholesterol (Chol.) using the method of Siedel et al. (1983); liver glycogen by the method of Carroll et al. (1956); glutathione (GSH) by the method of Tietze (1969) and lipid peroxide (Thio-barbituric acid reactive substance TBArs) - the method of Ohkawa et al. (1979). Protein fractions separation was carried out using electrophoretic SDS-Page electrophoresis analysis according to the method of Laemmli (1970). The marker, SDS-page molecular weight standard mixture (sigma) was applied to the first well. Scanning was applied using gel prosoftware programme.

\section{Statistical Analysis}

Analysis of data including t-test values and probabilities $(\mathrm{P})$ were used. The levels of significance were expressed as very highly significant $(\mathrm{P}<0.001)$, highly significant $(\mathrm{P}<0.01)$ and significant $(\mathrm{P}<$ $0.05)$ according to Snedecor and Cochran (1967). The percentage of change of each parameter from the corresponding control value was also calculated.

\section{Results}

\section{A. Biochemical assay}

1. Tissues-Total lipid (T.L.)

Table (1) revealed that coumarin treatment at a dose of $100 \mathrm{mg} / \mathrm{kg} . \mathrm{b} . \mathrm{w}$. caused insignificant changes in brain T.L. (-1.6\%), liver $(-1.45 \%)$ and kidney $(0.57 \%)$ while the dose of $200 \mathrm{mg} / \mathrm{kg}$. b.wt. caused significant decrease in T.L. of brain $(-10.9 \%)$, liver $(-16.7 \%)$ and insignificant change of kidney T.L. (-4.9\%).

\section{Tissues-Triglycerides (T.G.)}

It is evident from the results in Table (1) that there were insiginficant changes in tissues T.G. after the administration of coumarin at dose of 100 $\mathrm{mg} / \mathrm{kg}$.b.wt. Triglycerides (T.G.) of brain, liver and kidney reached to $-0.9 \%,-6.8 \%$ and $-0.76 \%$ respectively. The same Table (1) showed that the high dose of coumarin treated chicken $(200 \mathrm{mg} / \mathrm{kg}$.) caused a significant decrease in T.G. of brain and liver tissues $(-28.4 \%$ and $-25.8 \%$ respectively) and insignificant change of kidney T.G. (0.31).

\section{Tissues-Total Cholesterol (Chol.)}

Table (1) revealed that low dose of coumarin $(100 \mathrm{mg} / \mathrm{kg})$ administered to chicken resulted in non-significant changes in chol. content of brain, liver and kidney. The percentage of changes were $-3.2 \%$, $1.09 \%$ and $0.51 \%$ respectively compared with the control one. The high dose of coumarin $(200 \mathrm{mg} / \mathrm{kg})$ showed significant decrease in total cholesterol of brain and liver with percentage of changes reached to $-11.36 \%$ and $-26.9 \%$ respectively, while insignificant change in total cholesterol of kidney reached to $-5.8 \%$ compared with the control group.

\section{Tissues-glutathione content (GSH)}

Table (1) showed that coumarin at dose of $100 \mathrm{mg} / \mathrm{kg}$. treated chicken caused a significant decrease in GSH content of brain with percentage of change $-10 \%$ compared with control group, while the same dose caused non significant changes in GSH content of liver and kidney tissues with percentages of change reaching to $1.16 \%$ and $0.15 \%$ respectively. High dose $(200 \mathrm{mg} / \mathrm{kg})$ of coumarin caused a significant decrease $(p<0.001)$ in GSH content of all tissues under investigation. The percentages of change of brain, liver and kidney GSH content reaching to - 
$17.8 \%,-44 \%$ and $-16.55 \%$ respectively compared with the control group (Table 1).

\section{Tissues-lipid peroxide (TABrs)}

Table (1) showed that lipid peroxide (TABrs) content of brain and kidney exhibited non significant change in the coumarin - treated chicken $(100 \mathrm{mg} / \mathrm{kg} . \mathrm{G} 2)$ with percentage of change reaching to $1.7 \%$ and $-0.14 \%$ respectively, while $\mathrm{TABrs}$ indicator of liver recorded significant increase after $100 \mathrm{mg} / \mathrm{kg}$.b.wt. of coumarin treatment with percent of change $6.11 \%$ compared with the control group. The same Table (1) showed that lipid peroxide indicator (TBArs) elevated significantly after coumarin treatment at dose 200mg/kg (G3)in brain, liver and kidney of broiler chicken with percentage of change reaching to $3.86 \%, 11.68 \%$ and $4.9 \%$ respectively.

\section{Liver glycogen}

Both doses of coumarin $(100 \& 200$ $\mathrm{mg} / \mathrm{kg}$. G2 \& G3) resulted in a significant decrease of liver glycogen content of treated chicken with percentages of change reaching $-13.41 \%$ and $-30.4 \%$ respectively.

\section{Protein electrophoresis}

SDS polyacrylamide gel electrophoresis (PAGE) revealed that brain proteins of control (BG1) and treated chicken (BG2 \& BG3) were separated to 10 bands by using comassie brilliant blue stain (Fig. 1, Table 2). Figure 2, illustrates the scanning of the slab polyacrylamide brain proteins of the control (BG1), $100 \mathrm{mg} / \mathrm{kg}$ coumarin (BG2) and $200 \mathrm{mg} / \mathrm{kg}$ coumarin (BG3) treated chickens. The total number of bands in control (BG1) and treated (BG2 \& BG3) groups were in all of them (Fig. 2). The amount of separated protein in control (BG1) and treated (BG2 \& BG3) were 37.7, 27.3 and $25.1 \%$ respectively.

SDS polyacrylamide gel electrophoresis (PAGE) revealed that liver proteins of control and treated groups (LG2 \& LG3) were separated to 12 bands by using comassie brilliant blue stain (Fig. 1, table 2 ). Figure 3 illustrates the scanning of the slab polyacrylamide liver proteins of control (LG1) and treated (LG2 \& LG3) chickens. The total number of bands in control (LG1) and treated (LG2 \& LG3) groups were 8,6 and 5 respectively (Fig. 3 $\&$ Table 2). Six protein fractions of mol. w. 27.98, 24.96, 20.35, 15.40, 9.75 and 4.09 $\mathrm{KD}_{\mathrm{a}}$ appeared in control group (LG1) and disappeared (and other fractions with less mol.w. were appeared) in both coumarin treated groups (LG2 \& LG3). The total amount of liver protein fractions of control and treated groups were 31.2, 22.7 and $24.1 \%$ respectively.

SDS-polyacrylamide gel electrophoresis (PAGE) showed that kidney proteins of control (KG1) and treated groups (KG2 \& KG3) were separated to 11 bands by using comassie brilliant blue (COBB) stain (Fig. 1, Table 2). Figure 4 illustrates the scanning of the slab polyacrylamide kidney proteins of control (KG1) and treated (KG2 \& KG3) chickens. The total number of bands in control (KG1) and treated (KG2 \& KG3) groups were 7,5 and 5 respectively (Fig. 4 $\&$ table 2). Two protein fractions of mol.w. 25.15 and $1.56 \mathrm{KD}_{\mathrm{a}}$ appeared in control group (KG1) and disappeared in both coumarin treated groups (KG2 \& KG3). The total amount of kidney protein fractions of control and treated groups were $27.6,23.5$ and 37.9 respectively. 
Table (1): Effect of coumarin administration on lipid constituents, cholesterol, liver glycogen, glutathione and lipid peroxidase of brain, liver and kidney tissues of broiler chicken at two doses $(100 \& 200 \mathrm{mg} / \mathrm{kg}$.) for 10 days (every other day).

\begin{tabular}{|c|c|c|c|}
\hline Tissues $\quad$ Groups & $\begin{array}{l}\text { Control (G1) } \\
\mathrm{M} \pm \mathrm{SD}\end{array}$ & $\begin{array}{c}\text { Coumarin } \\
\text { (100mg.kg.G2) } \\
\mathrm{M} \pm \mathrm{SD} \\
\end{array}$ & $\begin{array}{c}\text { Coumarin } \\
(200 \mathrm{mg} / \mathrm{kg} \cdot \mathrm{G3}) \\
\mathrm{M} \pm \mathrm{SD} \\
\end{array}$ \\
\hline \multicolumn{4}{|l|}{ Brain } \\
\hline T.L. (mg/g.) & $18.96 \pm 1.52$ & $18.66 \pm 1.41$ & $16.9 \pm 0.51^{* *}$ \\
\hline$\%$ Change & & $(-1.6 \%)$ & $(-10.87 \%)$ \\
\hline T.G. (mg/g.) & $15 \pm 1.5$ & $14.86 \pm 1.07$ & $10.74 \pm 1.01^{* * * *}$ \\
\hline$\%$ Change & & $(-0.93 \%)$ & $(-28.4 \%)$ \\
\hline T.Chol. (mg/g.) & $8.1 \pm 0.5$ & $7.84 \pm 0.3$ & $7.18 \pm 0.6^{* *}$ \\
\hline$\%$ Change & & $(-3.2 \%)$ & $(-11.36 \%)$ \\
\hline GSH (mg/g.) & $0.82 \pm 0.05$ & $0.74 \pm 0.06^{* *}$ & $0.67 \pm 0.04^{* * *}$ \\
\hline$\%$ Change & & $(-10 \%)$ & $(-17.8 \%)$ \\
\hline TABrs (n mol./g.) & $136.44 \pm 3.9$ & $138.8 \pm 1.4$ & $141.7 \pm 2.4^{* *}$ \\
\hline$\%$ Change & & $(+1.7 \%)$ & $(+3.86 \%)$ \\
\hline \multicolumn{4}{|l|}{ Liver } \\
\hline T.L. (mg/g.) & $26.24 \pm 1.56$ & $25.86 \pm 1.71$ & $21.86 \pm 2.19^{* * * *}$ \\
\hline$\%$ Change & & $(-1.45 \%)$ & $(-16.7 \%)$ \\
\hline T.G. (mg/g.) & $19.96 \pm 2.5$ & $18.6 \pm 1.7$ & $14.8 \pm 0.9^{* * *}$ \\
\hline$\%$ Change & & $(-6.8 \%)$ & $(-25.8 \%)$ \\
\hline T.Chol. (mg/g.) & $9.16 \pm 1.3$ & $9.3 \pm 0.9$ & $6.7 \pm 0.95^{* * *}$ \\
\hline$\%$ Change & & $(1.09 \%)$ & $(-26.9 \%)$ \\
\hline GSH (mg/g.) & $1.72 \pm 0.43$ & $1.7 \pm 0.3$ & $0.95 \pm 0.3^{* *}$ \\
\hline$\%$ Change & & $(-1.16 \%)$ & $(-44 \%)$ \\
\hline TABrs (n mol./g.) & $171.18 \pm 2.05$ & $181.64 \pm 3.8^{* * * *}$ & $191.18 \pm 1.5^{* * * *}$ \\
\hline$\%$ Change & & $(+6.11 \%)$ & $(+11.7 \%)$ \\
\hline $\begin{array}{l}\text { Glycogen }(\mathrm{mg} / \mathrm{g} .) \\
\% \text { Change }\end{array}$ & $31.48 \pm 1.9$ & $\begin{array}{c}27.3 \pm 1.7^{* * * *} \\
(-13.4 \%)\end{array}$ & $\begin{array}{c}21.9 \pm 1.8^{* * *} \\
(-30.4 \%)\end{array}$ \\
\hline \multicolumn{4}{|l|}{ Kidney } \\
\hline T.L. (mg/g.) & $17.5 \pm 0.7$ & $17.64 \pm 0.52$ & $16.7 \pm 0.9$ \\
\hline$\%$ Change & & $(0.05 \%)$ & $(-4.9 \%)$ \\
\hline T.G. (mg/g.) & $13.1 \pm 1.02$ & $12.98 \pm 0.9$ & $13.12 \pm 0.9$ \\
\hline$\%$ Change & & $(-0.8 \%)$ & $(0.31 \%)$ \\
\hline T.Chol. (mg/g.) & $7.9 \pm 0.6$ & $7.94 \pm 0.4$ & $7.44 \pm 0.8$ \\
\hline$\%$ Change & & $(0.51 \%)$ & $(-5.8 \%)$ \\
\hline GSH (mg/g.) & $0.683 \pm 0.07$ & $0.684 \pm 0.09$ & $0.57 \pm 0.05^{* *}$ \\
\hline$\%$ Change & & $(0.15 \%)$ & $(-16.6 \%)$ \\
\hline $\begin{array}{l}\text { TABrs (n mol./g.) } \\
\% \text { Change }\end{array}$ & $131.24 \pm 2.22$ & $\begin{array}{c}131.06 \pm 2.6 \\
(-0.14 \%)\end{array}$ & $\begin{array}{c}150.8 \pm 9.75^{* * *} \\
(+14.9 \%)\end{array}$ \\
\hline
\end{tabular}

- * significant $\quad * *$ highly significant $\quad * * *$ very highly significant

- values are expressed as mean \pm SD.

- Number between parentheses indicate percentage of change from the corresponding control value. 
Shadia, A. Radwan 
Fig. (1) Brain, liver and kidney protein electrophoresis
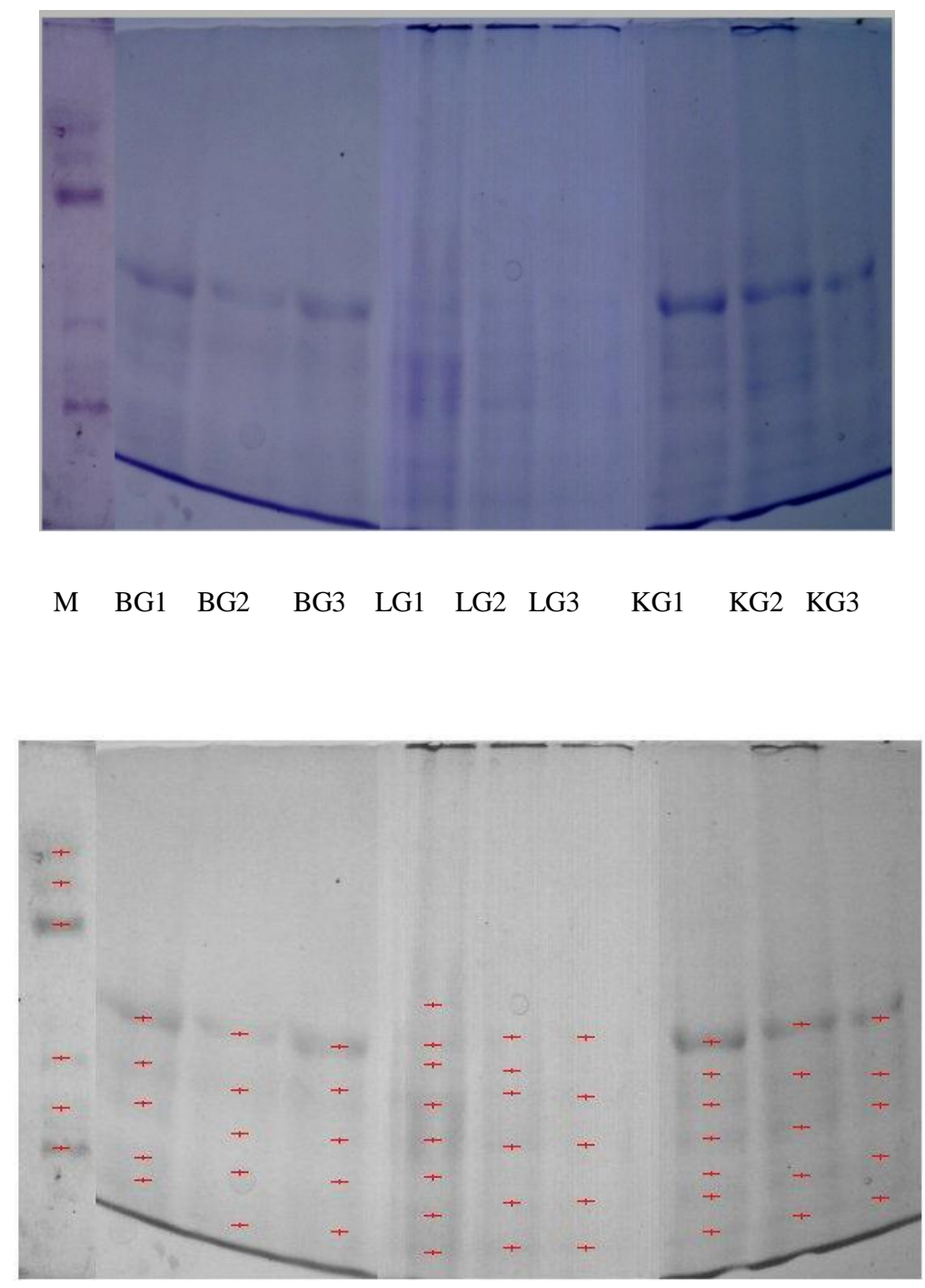

$\mathrm{M}=$ Marker

BG1 = Brain electrophoretic pattern of control chicken group (G1).

BG2 = Brain electrophoretic pattern of coumarin - treated chicken group (100mg/kg.b.w-G2).

BG3 = Brain electrophoretic pattern of coumarin - treated chicken group (200mg/kg.b.w-G3).

LG1 = Liver electrophoretic pattern of control chicken group (G1).

LG2 $=$ Liver electrophoretic pattern of coumarin - treated chicken group $(100 \mathrm{mg} / \mathrm{kg}$. b.w-G2 $)$.

LG3 = Liver electrophoretic pattern of coumarin - treated chicken group $(200 \mathrm{mg} / \mathrm{kg} . b . \mathrm{w}-\mathrm{G} 3)$.

$\mathrm{KG1}=$ Kidney electrophoretic pattern of control chicken group (G1).

$\mathrm{KG} 2=$ Kidney electrophoretic pattern of coumarin - treated chicken group (100mg/kg.b.w-G2).

KG3 = Kidney electrophoretic pattern of coumarin - treated chicken group (200mg/kg.b.w-G3). 


\section{Shadia, A. Radwan}

Fig. (2)
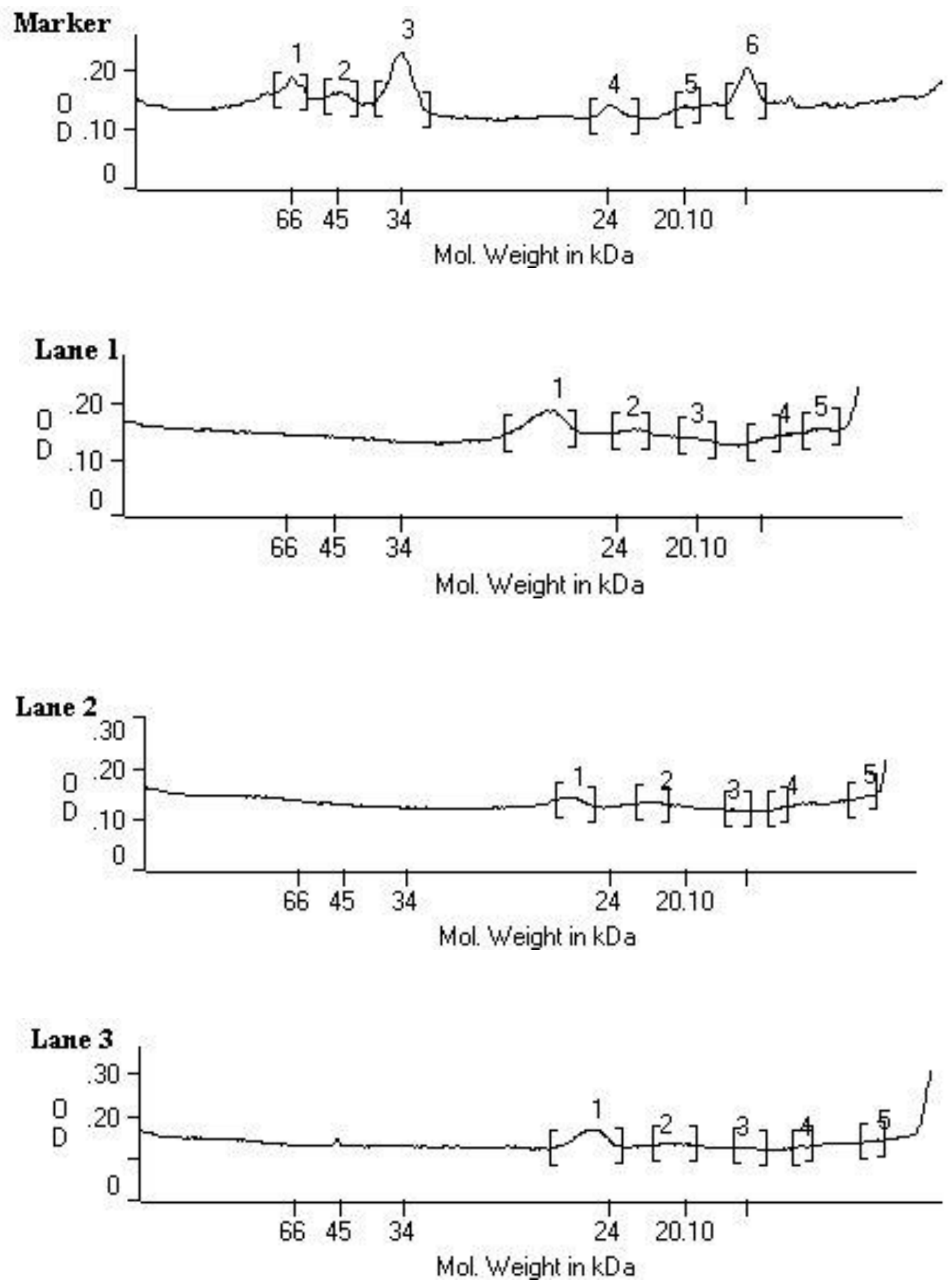

The brain protein fractions as revealed by the scanning of the slab polyacrylamide: Lane $1=$ Brain of the control chicken group (G1).

Lane $2=$ Brain of the coumarin - treated chicken (100mg $/ \mathrm{kg} . \mathrm{G} 2)$.

Lane 3 = Brain of the coumarin - treated chicken (200mg/kg.G3). 
Fig. (3)
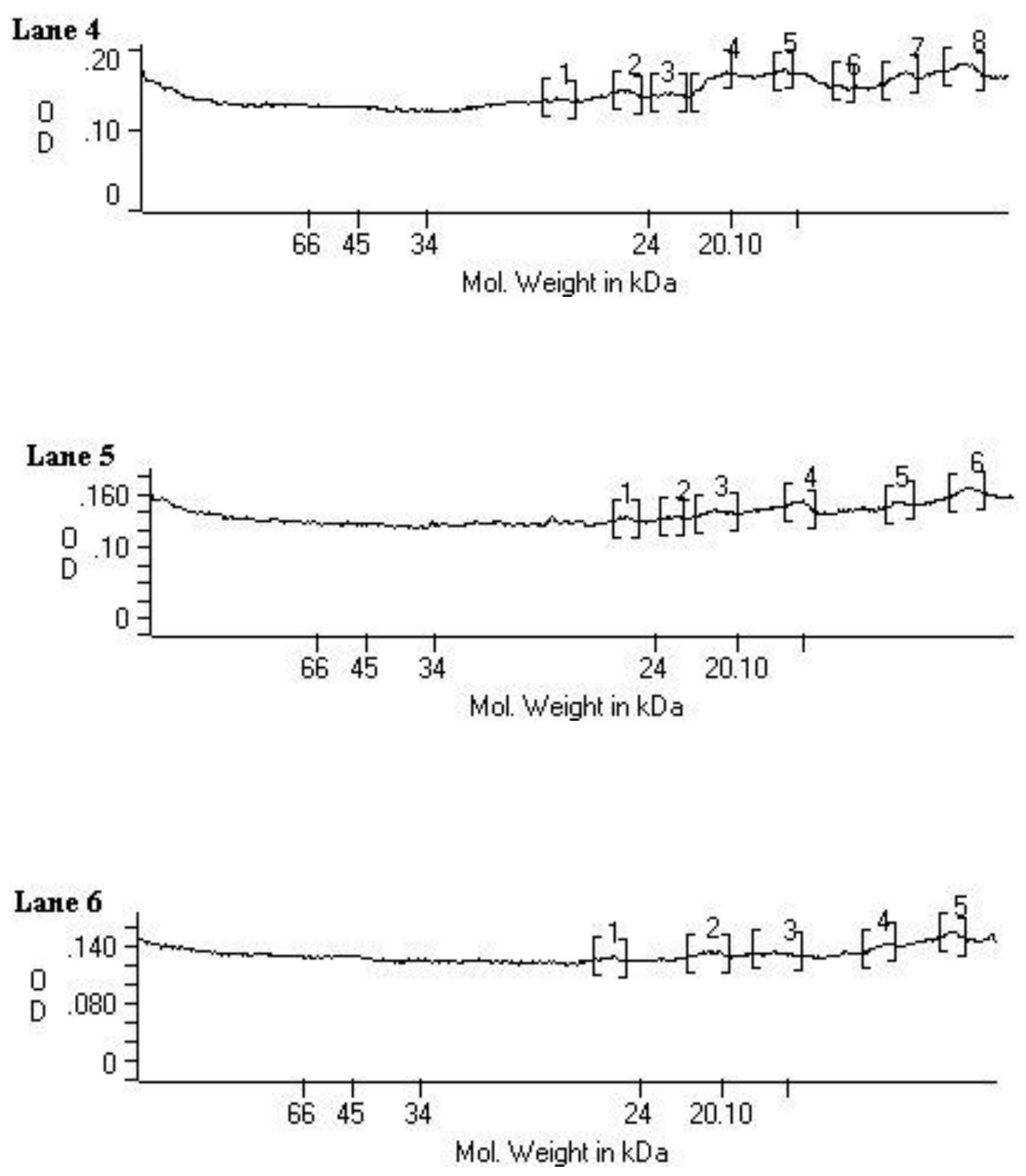

The liver protein fractions as revealed by the scanning of the slab polyacrylamide:

Lane 4 = Liver of the control chicken group (G1).

Lane $5=$ Liver of the coumarin - treated chicken $(100 \mathrm{mg} / \mathrm{kg} . \mathrm{G} 2)$.

Lane $6=$ Liver of the coumarin - treated chicken (200mg/kg.G3). 
Fig. (4)
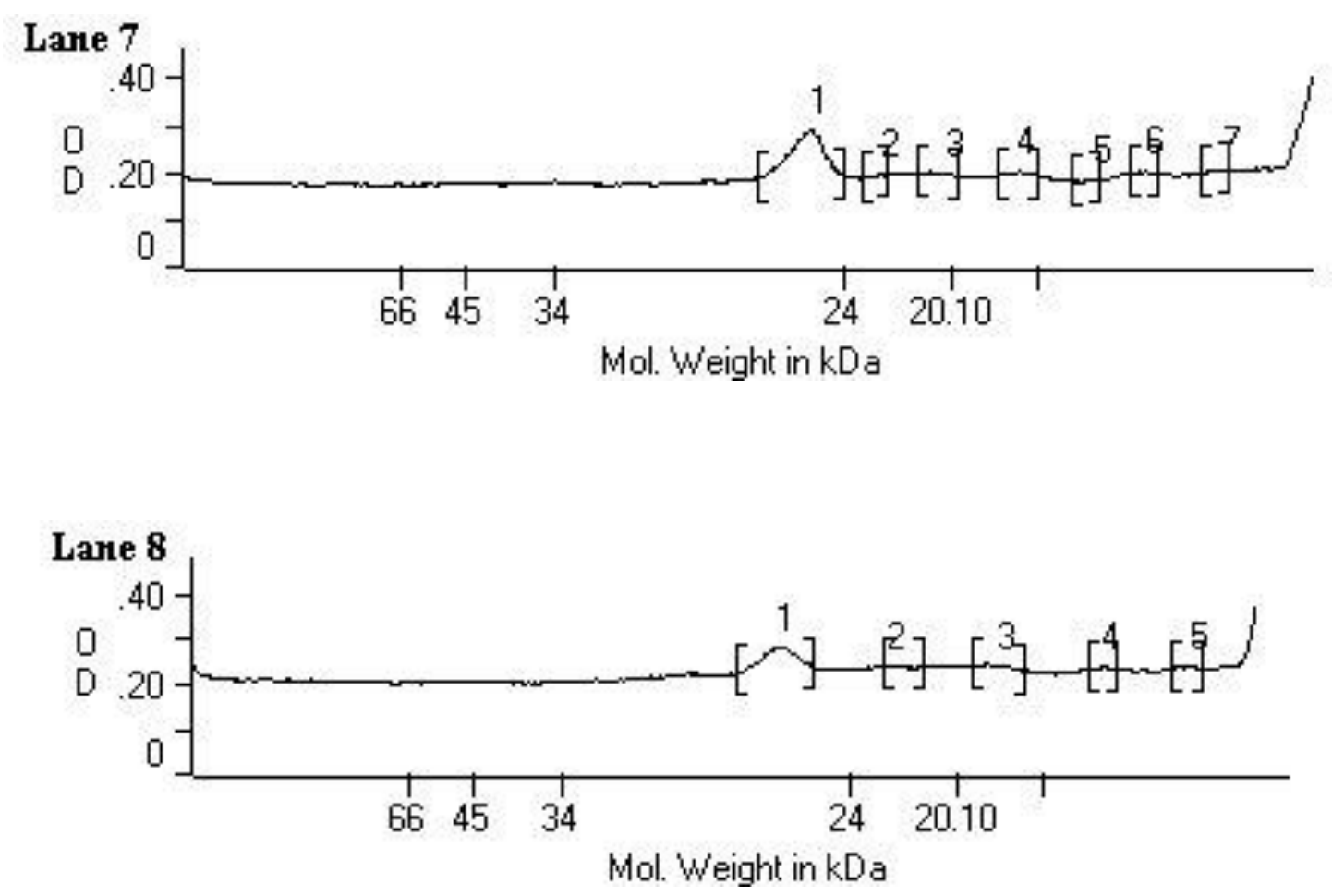

\section{Lane 9}

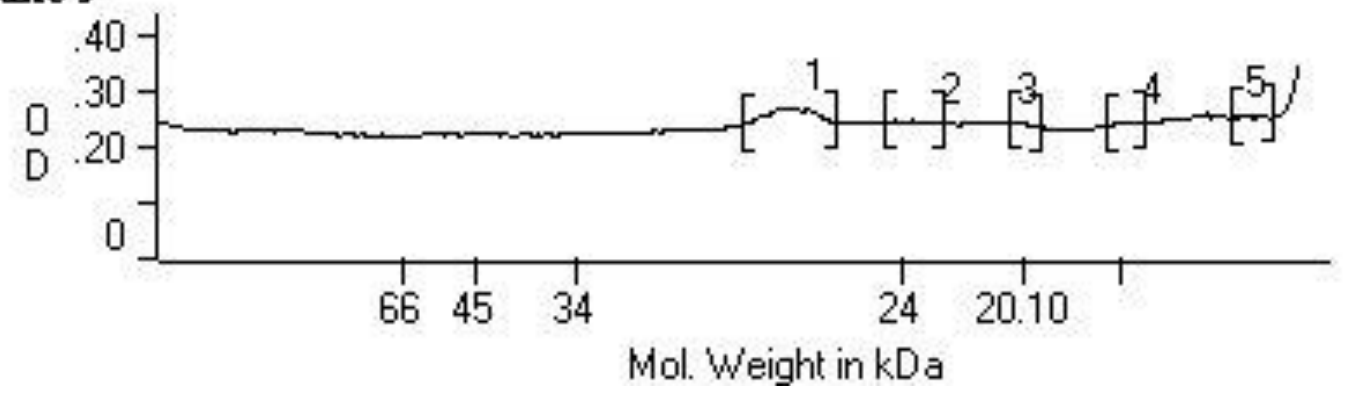

The kidney protein fractions as revealed by the scanning of the slab polyacrylamide:

Lane $7=$ Kidney of the control chicken group (G1).

Lane $8=$ Kidney of the coumarin - treated chicken (100mg/kg.G2).

Lane $9=$ Kidney of the coumarin - treated chicken $(200 \mathrm{mg} / \mathrm{kg} . \mathrm{G} 3)$. 


\section{Discussion}

The present data showed that the low dose of coumarin $(100 \mathrm{mg} / \mathrm{kg})$ caused non significant change in the lipid constituents (T.L \& TG) and cholesterol of brain, liver and kidney tissues of broiler chicken. On the other hand, the high dose of coumarin (200 mg/kg) showed a significant decrease in the lipid constituents (T.L. \& TG) and cholesterol of brain and liver only, but non significant changes was recorded in T.L, T.G. and Chol. of kidney tissue. Hoult and Paya (1996) studied the pharmacological actions of some synthetic coumarin derivatives. They recorded that some derivatives have lipolysis action. According to Hanlikun et al. (1998) the extract of Astilbe thunbergii rhizomes (from commercial source in Japan) (coumarin containing extract) enhanced norepinep-hrine induced lipolysis at concentrations of 10$1000 \mathrm{micro} \mathrm{g} / \mathrm{ml}$.

Many authors studied the effect of plant extracts containing coumarin (s) on the lipid constituents, cholesterol, protein and some metabolizing enzymes in serum and tissues of rats (Beamand et al., 1998; Ezeanyika et al., 1999; Ezeanyika and Obidoa, 2000; Yazdanparast and Alavi, 2001 and Adam et al., 2005). In agreement with the present study, Yazdanparast and Alavi (2001) studied serum triglycerides and total cholesterol levels in rats (with hyperlipidemia induced by diet) after oral administration of a water extract (coumarincontaining extract) of Anethum graveolens leaves. The authors came to conclusion that the administration of aqueous extraction for 14 consecutive days reduced the triglycerides and $\mathrm{T}$. cholesterol levels by almost 50 and $20 \%$, respectively. Also, they found that oral administration of the essential oil of A. graveolens seeds, at two different doses, also reduced the triglycerides levels by almost $42 \%$, while T-cholesterol level was not reduced by the same doses of the essential oil. Besides, Adam et al. (2005) stated that a possible lipid peroxidation enhanced by coumarin in the liver can be controlled by troxorutin (drug) as cofactor when therapy with coumarin was adopted.
The authors pointed out that these adverse effect caused by coumarin can be detected only in high concentration considerably above the regular therapeutical dosage. Finally, they concluded that troxorutin is a beneficial cofactor in coumarin preparations used for the therapy of chronic venous insufficiency. The present study showed that the high dose (200 $\mathrm{mg} / \mathrm{kg}$. b.wt.) of coumarin affected significantly both glutathione (GSH) content and lipid peroxide indicator (TABrs) in brain, liver and kidney tissues of broiler chicken. In addition, both doses of coumarin $(100 \&$ $200 \mathrm{mg} / \mathrm{kg}$.) affected significantly liver glycogen (decreasing) and lipid peroxide (increasing). According to Ulubelen et al. (1994), coumarins and alkaloides were isolated from the plant and tested in vivo for antifertility activity. The isolated substances showed antifertility activity, $70 \%$ of the tested animals developed cystic and atretic follicles in their ovaries and glomerulocapsular adhesion and segmental fusion was observed in the kidneys. No harmful effect was observed in the brain. The alkaloids (but not coumarin) showed no antifertility activity.

Moreover, Ezeanyika et al. (1999) study the comparative effects of scopoletin and cyanide on rat brain-histopathologically. Their results showed that relative brain weights of the rats fed scopoletin (coumarin derivatives) were significantly less than that of control from the $3^{\text {rd }}$ month of fed ration. They recorded non significant change in the lipid peroxide levels of the rat brains in the various groups. Also, the histological examination of the brains of rats suggested that scopoletin is involved in the pathogenesis of the neuropathy seem in cassava (fed ration) consuming populations. Ezeanyika and Obidoa (2000) concluded that there was a significant decrease $(\mathrm{P}<0.5)$ of the glucose-6-phosphates activity and significant increase $(\mathrm{P}<0.05)$ in glutathioneS-transferase activity in the group fed scopoletin + cyanide. The present study revealed that SDS-(PAGE) showed 
decrease in the fractionated protein amounts after treatment with both coumarin doses. According to Ezeanyika and Obidoa (2000), a significant decrease $(P<0.05)$ in relative microsomal protein content (mg/g.liver tissue) was recorded in scopoletin fed group compared to control rats. Additionally, Adam et al. (2005) claimed that the concentrations of hepatic ATP and oxidized and total glutathione decreased after coumarin treatment $(4 \mathrm{~m} \mathrm{~mol} / \mathrm{L})$ in the isolated perfused rat liver. Many authors recorded the benefit and curative effect of coumarin (Casley et al., 1993; Hault \& Paya, 1996; Tanaka et al., 1998; Lieshout et al., 1998; 1999 and Kelly et al., 2000).

\section{Reference}

1. Adam, B.S.; Pentz, R.; Siegeres, C.P.; Strubelt, O. and Tegtmeier, M. (2005): Troxorutin protects the isolated prfused rat liver from a possible lipid peroxidation by coumarin. Phytomedicine, 12(1/2): 52-61.

2. Beamand, J.A.; Barton, P.T.; Price, R.J. and Lake, B.G. (1998): Lake of effect of coumarin on unscheduled DNA synthesis in precision-cut human liver slices. Food and chemical toxicology, 36(8): 647-653.

3. Carlton, B.D.; Aubrum, J.C. and Simon, G.S. (1996): Effect of coumarin following perinated and chronic exposure in Sprage Dawley rats and CD-1 mice. Fundan Appl Toxicol, 30 (1): 145-151.

4. Carroll, N.V.; Longle, R.W. and Roe, J.H. (1956): The determination of glycogen in liver and muscle by use of anthrone reagent. J Biol Chem, 220: 583-593.

5. Casley-smith, J.R.; Jamal, S. and Casley5with-Judith-R (1993): Reduction of filaritic lymphoedema and elephantiasis by 5,6 benzo-alpha-pyrone (coumarin), and the effects of diethylcarbamazine (DEC). Annal. Trop. Med. \& Paras., 87 (3): 247258.

6. Dhami, M.S.; Drangova, R.; Farkas, R.; Balazs, T. and Fever, G. (1979): Decrease aminotransferase activity of serum and various tissues in the rat after cofazoilin treatment. Clin Chem, 25(7): 1203-1266.

7. Ezeanyika, L.U.S.; Obidoa, O. and Shoyinka, V.O. (1999): Comparative effect of scopoletin and cyanide on rat brain: Histopathology. Plant-Foods for Human Nutrition, 53(4): 351-358.
8. Ezeanyika, L.U.S. and Obidoa, O (2000): Comparative effects of scopoletin and cyanide on glucose-6-phosphatase and glutathione-S-transferase activities of rat liver miscosomes. Nutrition-Res., 20(2): 309-313.

9. Frings, L.; Christopher, S. and Dum, R. (1970): Colorimetric method for determination of total serum lipids based on the sulphophosphovanilline reaction. Am J Clin Path., 53: 89-91.

10. Goeger, D.E. and Anderson, K.E. (1991): Coumarin-induced changes in delta-aminolaevulinic acid synthase and cytochrome $\mathrm{p}$. 450 in chick embryoliver. Food Chem. Toxicol., 29(3): 145-151.

11. Goeger, D.E. a dn Anderson, K.E. (1992): Biochemical characterization of coumarin 7-hysdroxylase activity in chick embryo liver microsomes. Biochem. Pharmacol., 43 (2): 363-369.

12. Han-Likun; Ninomiya, H.; Tanyuchi, M; Baba, K.; Kimura, Y. and Okuda, H. (1998). Nor epinephrine-augmenting lipolytic effectors from Astilbe thunbergii rhizomes.J Natural Products,61(8):1006-1011.

13. Hoult, T.R.S. and Paya, M. (1996): Pharmacological and biochemical actions of simple coumarins : natural products with therapeutic potential. General-pharmacology, 27(4): 713-722.

14. Kelly, V.P.; Elis, E.M.; Manson, M.M. et al. (2000): Chemoprevention of aflatoxin B1 hepatocarcinogenesis by coumarin, a natural benzopyrone that is a potent inducer of aflatoxin B1-aldhyde reductase, the glutathione S-transferase A5 and P1 subunits and NAD (P): Hiquinone oxides reductase in rat liver. Cancer, Res. Baltimore, 60 (4): 957-969.

15. Laemmli, UK (1970): Cleavage of structural proteins during the assembly of the head of bacteriophage T4. Nature, 227: 680-685.

16. Lake, B.G. (1999): Coumarin mtabolism, toxicity and carcinogenicity: relevance for human risk assessment. Food and Chemical-toxicology, 37(4): 423-453.

17. Lieshout, E.M.M.; Bedaf, M.M.G; Peter, M.; Ekkel, C.; Nij.hof, W.A. and Peters, W.A. and Peters, W.H. (1998): The effect of dietary anticarcinogens on rat gastrointestinal glutathione S-transferase theta 1-1 levels, Carcinogenesis, 19 (11): 2055-2057.

18. Mohanty, S.K. and Sahoo, N.C. (1992): Effect of soaking period, seed size and growth regulators on inhibition and 
germination of seeds of some field crops. Oriss-J. Agric. Res., 5 (1-2): 30-35.

19. Ohkawa, J.; Ohish, N. and Yagi, K. (1979): Assay for lipid peroxidase in animal tissues by thiobarbituric acid reaction. Anal. Biochem. 95: 35.

20. Radwan S.A. (2000): Biochemical, histopathological and ultrastructural alterations in the liver and kidney of albino mice treated with coumarin. J. Egypt. Ger. Soc. Zool., 33 (C): 337-361.

21. Rang, H.P. and Dale, M.M. (1991): Pharmacology, $2^{\text {nd }}$ ed. pp. 116-117. Churchill-Livingstone.

22. Ryakhovskaya, T.V.; Ushbaera, G.G. and Kukenov, M.K. (1989): Studying the biological activity of the phenol complex of agrimony Agrimonia asiatica. Ser. Biol., 10 (2): 188-190.

23. Siedel, J.; Hagele, E.O.; Ziegenhorn, J. and Wahlefeld, A.W. (1983): Reagent for enzymatic determination of serum total cholesterol with improved lipolytic efficiency. Clin. Chem., 29(6): 1072-1080.

24. Snedecor, G.W. and Cochran, W.G. (1967): Statistical methods, $6^{\text {th }}$ ed. Iowa State Univ. Press. Iowa. U.S.A.

25. Tanaka, T.; Kawabata, K.; Kakumoto, M.; Hara, A. and Ohigashi, H. (1998): Citrus auraptene exerts dose-dependent chemopreventive activity in rat large bowel tumorigenesis. The inhibition correlates with suppression of cell proliferation and lipid peroxidation and with induction of phase II drug-metabolizing enzymes. Cancer.Res. Baltimore. 58 (12): 2550-2556.

26. Tietze, F. (1969): Enzymatic method for the quantitative determination of nanogram amounts of total oxidized glutathione. Anal. Biochem., 27: 502-522.

27. Tligui, N. and Ruth, G.R. (1994): Ferula communis variety bravifolia intoxication of sheep. Am. J. Vete. Res., 55 (11): 15581653.

28. Ulubelen, A.; Ertygrul, L.; Brmon, H. et al. (1994): Antifertility effects of some coumarin isolated from Ruta Chalepensis and R. Chalepensis Var. latifolia in Rodents. Phytotherapy Res., 8 (4): 233-236.

29. Yazdanparast, R. and Alavi, M. (2001): Antihyperlipidaemic and Antihyper-cholesterolaemic effects of Anethum graveolens leaves after the removal of furacoumarins. Cytobios, 105 (410): 185-191.

30. Yourick, J.J. and Bronaugh, R.L. (1997): Percutaneous absorption and metabolism of coumarin in human and rat skin. J. Appl. Toxicol., 17 (3): 153-158.

31. Zollner, N. and Kirsch, K. (1962): Micro determination of lipids by sulfophosphovanillin reaction. Z. Exp. Med., 135: 54560. 


\section{التغيرات الناتجة فى بعض القياسات البيوكيميائية ونمط الفصل الكهربى الكيى للبروتين فى بعض أنسجة الاجاج البلاى المعامل بالكومارين}

\section{شادية على رضوان}

قسم العلوم البيولوجية والجيولوجيا - كلية التربية - جامعة عين شمس رفس

الكومارين مادة توجد طبيعياًَفى المكونات الغذائية وبعض أوراق وجذور النباتات ـ إنيات

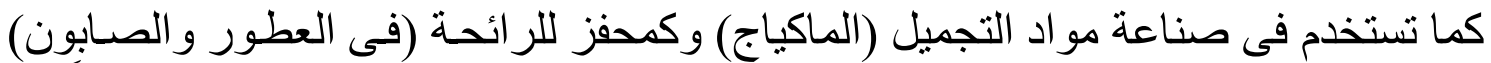

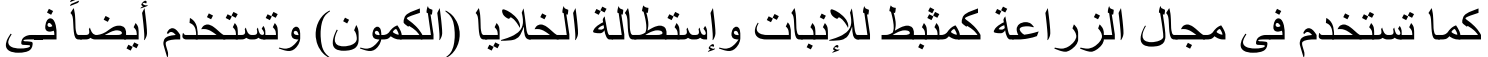

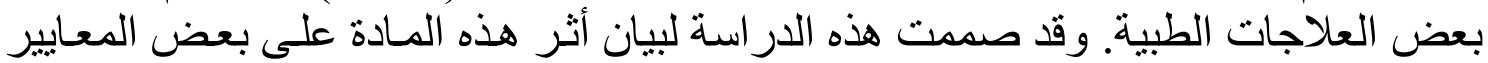

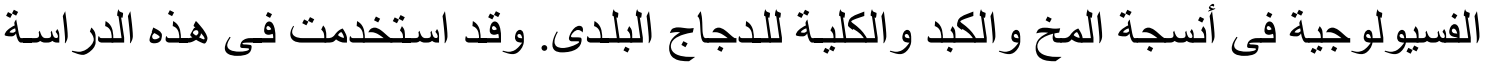

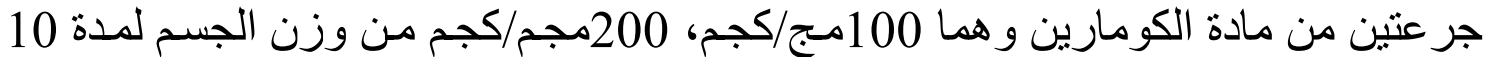

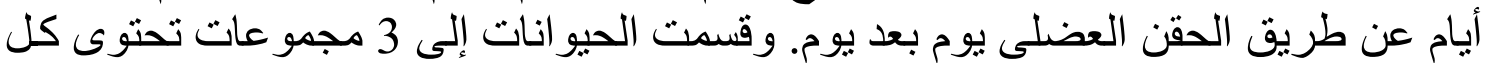

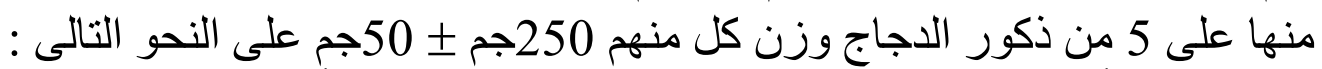

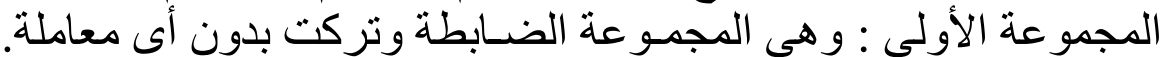

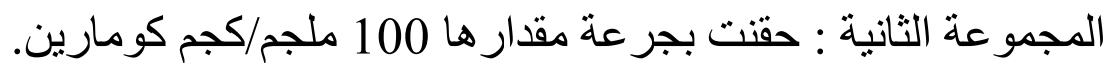

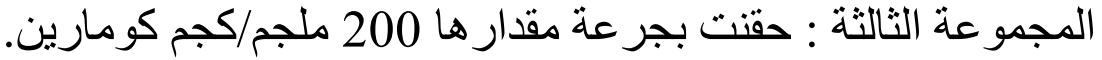
وقد أسفرت الدراسة عن النتائج البيوكيميائية التالية :

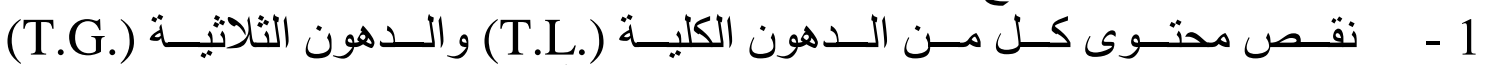

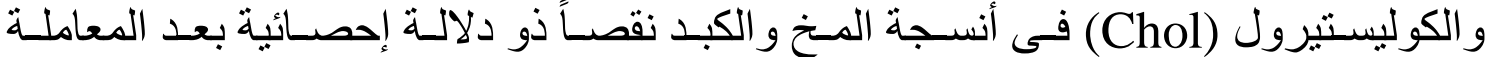

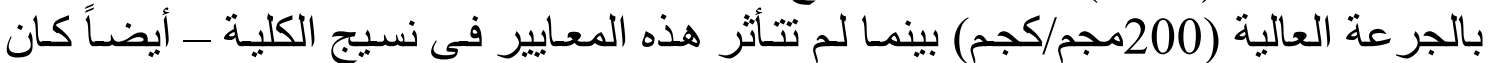

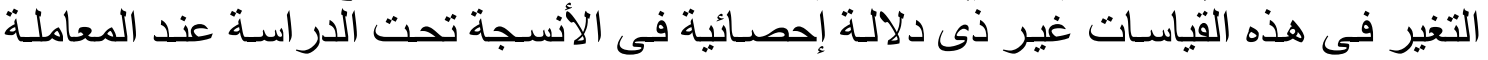

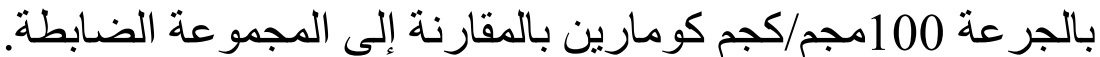

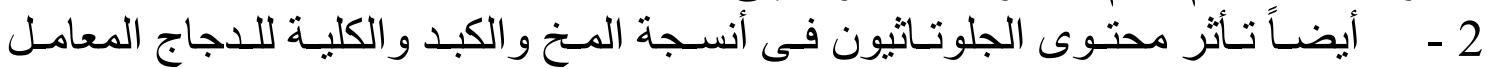

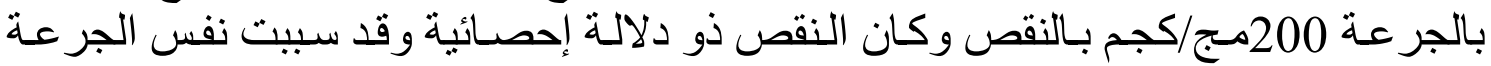

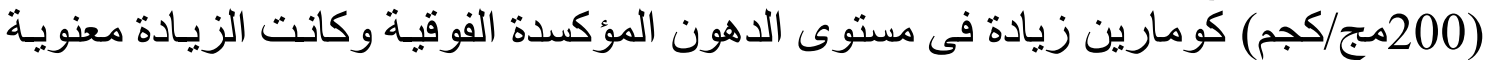

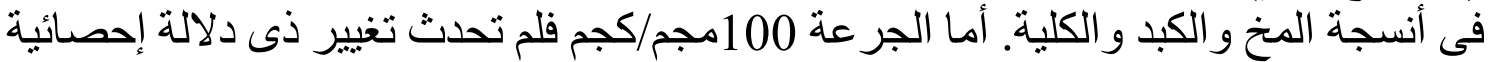

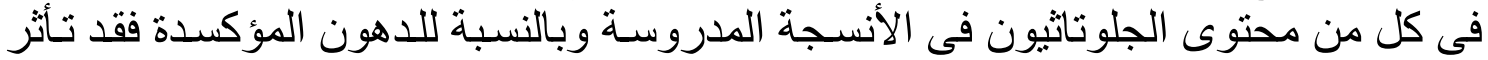

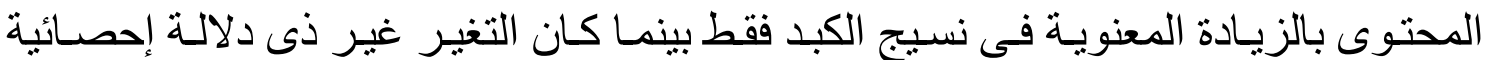

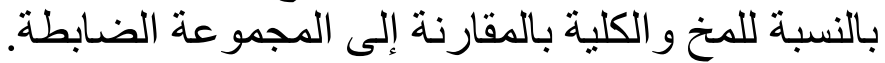

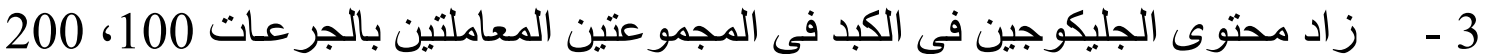

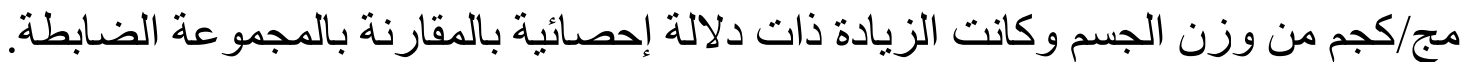

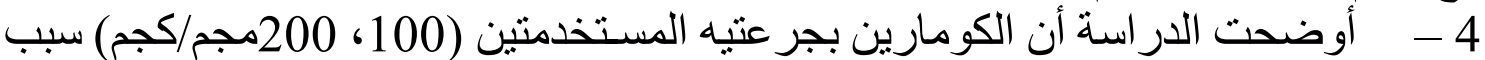

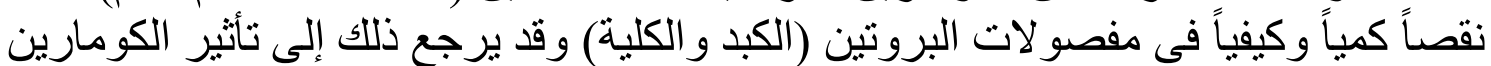
Xenobiotic

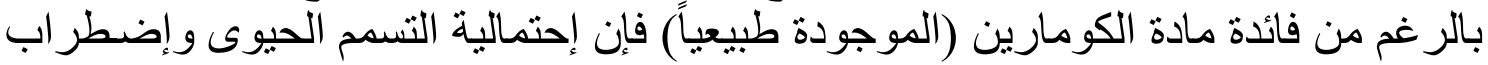

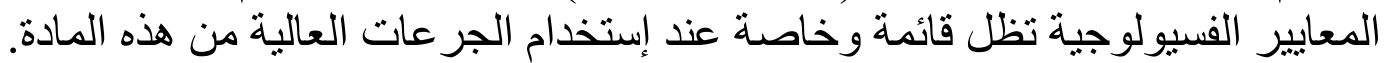


